\title{
Steel-Corrosion Characteristics of an Environmental Inhibitor using Limestone Sludge and Acetic Acid
}

\author{
Hwa-Sung Ryu ${ }^{1)}$, Deuck-Mo Kim ${ }^{1), *}{ }_{\mathbb{D}}$, Sang-Heon Shin ${ }^{1)}$, Won-Jun Park ${ }^{2)}$, and Seung-Jun Kwon ${ }^{3)}$
}

(Received September 18, 2017, Accepted January 15, 2018)

\begin{abstract}
Calcium acetate, which can be used in concrete to shorten the construction period and to improve productivity, was manufactured using limestone sludge and acetic acid. Calcium acetate contains a carboxyl group, and it can provide anticorrosive properties by forming a complex with the steel surface. We evaluated the basic performance of a carboxylic early-strength agent produced from industrial by-products (limestone sludge and acetic acid) as a corrosion inhibitor. A comparative evaluation was performed using calcium nitrate, which is a conventional early-strength agent; the corrosion area ratio, corrosion state, and electrochemical performance of a steel plate immersed in aqueous solutions were evaluated. A steel plate immersed in calcium acetate was not substantially corroded. The electrochemical investigations showed a high corrosion potential based on the impedance characteristics. The corrosion current showed anodic values, and no corrosion occurred on the surface of the steel plate because of the adsorption of carboxyl groups. Scanning electron microscopy indicated that the steel plate was covered by a crystalline coating, which suppressed corrosion. We show that it is possible to develop an environmentally friendly recycling method as an early-strength agent and corrosion inhibitor when manufacturing calcium acetate using limestone sludge.
\end{abstract}

Keywords: steel, corrosion, inhibitor, limestone sludge, acetic acid.

\section{Introduction}

Deicing agents are used in large quantities to remove snow from road surfaces in winter; chloride-based deicing agents are the most widely used (Federal Highway Administration 2002; Mussato 2003). However, chloride accelerates the corrosion of steel materials and concrete; to prevent these negative effects, the agent was mixed with a corrosion inhibitor. Wet deicing agents can be mixed with a liquid corrosion inhibitor, such as an amine or amino alcohol; however, solid-state deicing agents are more difficult to handle because they cannot be used with a liquid corrosion inhibitor. To inhibit the corrosion caused by chloride-based deicing agents, the use of an acetate compound, such as calcium magnesium acetate or calcium nitrate, has been proposed. Currently, these inhibitors are expensive and their effect is minimal; therefore, strategies to solve these problems are urgently needed (Shi et al. 2009, 2010).

Concrete agents are chemical materials that improve the fluidity, hydration, and durability of concrete. Early-strength

\footnotetext{
${ }^{1)}$ Hanyang Experiment and Consulting Co, $1271 \mathrm{Sa}$ 3-dong, Ansan 15588, Republic of Korea.

*Corresponding Author; E-mail: golanhae@naver.com

${ }^{2)}$ Department of Building System Engineering, Kangwon National University, Samcheok 25913, Republic of Korea.

${ }^{3)}$ Department of Civil Engineering, Hannam University, Daejeon 34430, Republic of Korea.
}

Copyright $($ The Author(s) 2018. This article is an open access publication concrete agents are important materials for reducing the construction period. Common early-strength concrete agents include calcium formate and calcium nitrate (Heikal 2004; Dodson 1990; NS Berke and ARosenberg 1989; Hoang et al. 2016; Messina et al. 2015; Çetin et al. 2016).

High early-strength concrete shows a deteriorated longterm strength and durability because of the rapid formation of hydrates (Thamas et al. 2015; Hansen 1987; Han 1991; Bazant and Baweja 1996). Concrete with reduced durability is characterized by cracks from expansion because of corrosion of the inner steel reinforcement.

Early-strength agents with carboxyl groups can improve the compressive strength of concrete by promoting the hydration of cement. Materials that have carboxyl groups and can be used as early-strength agents include calcium acetate and calcium formate. Calcium acetate and calcium formate can improve the strength of cement by promoting hydration of the gypsum component and C3A therein (Min et al. 2014; Le Saoût et al. 2013; Huang and Shen 2014). These early-strength agents are known to possess anti-corrosive properties (Monticelli et al. 2000).

Earlier work confirmed that mixing $1 \%$ calcium acetate manufactured from limestone sludge with $1 \mathrm{wt} \%$ cement could accelerate the hydration of cement and improve its early strength (Kim et al. 2016).

Figure 1 shows the corrosion characteristics of several types of inhibitors against chloride ions. Amines and alkanolamines exhibit a moderate efficacy as corrosion inhibitors (Ormellese et al. 2009). 
Corrosion is more likely for higher absolute values of the corrosion potential. As shown in Fig. 1, when the chlorine ion concentration is $1.0 \mathrm{~mol} / \mathrm{L}$, the carboxyl group exhibits a higher resistance to corrosion than amines and amino acids. Carboxylates exhibit the best corrosion resistance (Ormellese et al. 2009). They also show better anti-corrosive properties than sodium nitrite, which is a conventional corrosion inhibitor.

Quicklime is used to remove gaseous sulfuric acid that is generated during steel manufacturing. The limestone used for producing quicklime is pretreated using a washing method to prevent the powders from clogging the piping and to ensure that air reaches the kiln. Large amounts of industrial byproducts are generated during this washing process and are collectively termed limestone sludge (LSS). A separate process is required to deal with these by-products (World Steel Association 2015; Seo et al. 2014). In this study, calcium acetate, which is the main raw material for carboxylic early-strength agents, was produced using LSS and an organic acid. We evaluated the corrosion-inhibiting characteristics of solid-state carboxyl-based calcium acetate generated by a reaction with an organic acid that can be used as a corrosion inhibitor with LSS.

Calcium acetate, which can be used as a concrete earlystrength agent using calcined sludge as an industrial byproduct, was prepared, and its corrosion characteristics were evaluated. For this purpose, the corrosion area ratio, corrosion weight loss, and electrochemical corrosion characteristics were evaluated after an iron plate was corroded using calcium chloride, calcium nitrate, and calcium acetate. Further, the surface of the steel sheet was examined using scanning electron microscopy (SEM).

\section{Experiment}

\subsection{Materials}

\subsubsection{Lime Stone Sludge}

LSS, an industrial by-product, was used to manufacture a calcium-containing high early-strength agent. The LSS had a

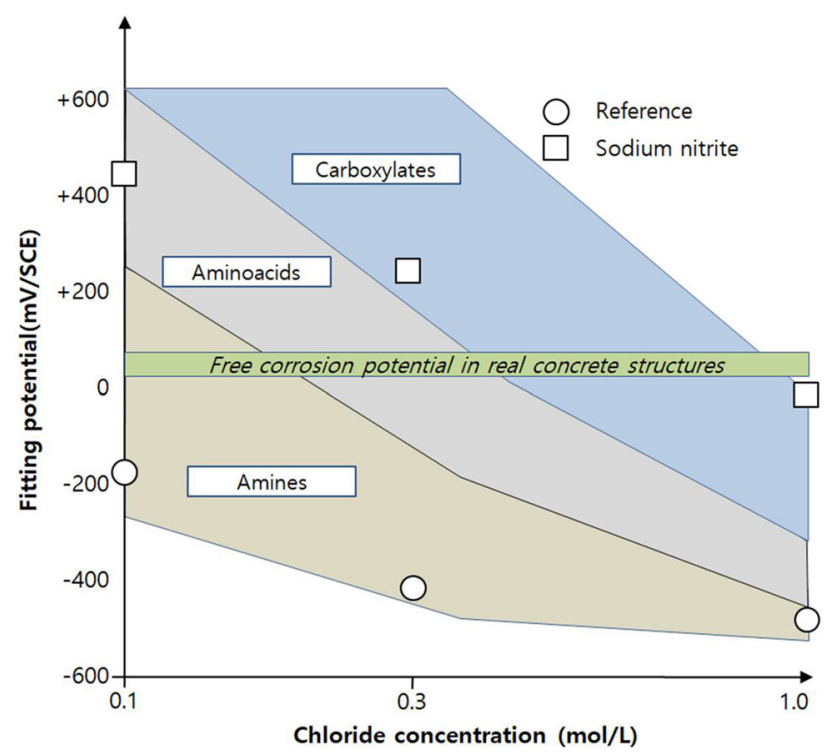

Fig. 1 Inhibitor specification on chloride concentration (Ormellese et al. 2009). density of $2.97 \mathrm{~g} / \mathrm{cm}^{3}$ and an average particle diameter of approximately $28.70 \mu \mathrm{m}$; the calcium carbonate had a density of $2.93 \mathrm{~g} / \mathrm{cm}^{3}$ and an average particle diameter $<40 \mu \mathrm{m}$.

The X-ray diffraction (XRD) results and chemical composition analyses of LSS are shown in Fig. 2 and Table 1, respectively. The XRD patterns of $\mathrm{CaCO}_{3}$ and LSS show a $\mathrm{CaCO}_{3}$ peak at approximately $29^{\circ}$. The structure of LSS appears to be the same as that of $\mathrm{CaCO}_{3}$. However, in terms of the chemical composition, the $\mathrm{CaO}$ content of LSS was roughly $5.84 \%$ less than that of $\mathrm{CaCO}_{3}$. Moreover, LSS contained $\mathrm{SiO}_{2}$ and metallic salts, such as $\mathrm{Al}_{2} \mathrm{O}_{3}$ and $\mathrm{Fe}_{2} \mathrm{O}_{3}$.

\subsubsection{Recycled Acetic Acid}

Recycled acetic acid (RAA) was obtained by separating the acids used in the etching processes. In this study, about $60 \%$ RAA was used. Figure 3 shows the Fourier transform infrared (FT-IR) analysis of RAA. The peaks in the range of $3300-2500 \mathrm{~cm}^{-1}$ are attributed to carboxylic groups. $\mathrm{C}=\mathrm{O}$ $\left(1760-1690 \mathrm{~cm}^{-1}\right)$ and $\mathrm{C}-\mathrm{O}\left(1320-1210 \mathrm{~cm}^{-1}\right)$ groups were also observed. Some examples of carboxylic acids are acetic acid, formic acid, gluconic acid, and propionic acid.

\subsubsection{Manufacturing of Calcium Acetate}

Figure 4 shows the schematic of the process used for manufacturing calcium acetate. In this study, RAA and LSS were made to react with each other to yield CA (Eq. 1). Maximum yield was obtained ( $1 \mathrm{~mol}$ each of $\mathrm{CA}$, water, and carbon dioxide for every $1 \mathrm{~mol}$ of $\mathrm{CaCO}_{3}$ ) at an acetic acid: $\mathrm{CaCO}_{3}$ ratio of $2: 1$.

$$
2 \mathrm{CH}_{3} \mathrm{COOH}+\mathrm{CaCO}_{3}=\mathrm{Ca}\left(\mathrm{CH}_{3} \mathrm{COO}\right)_{2}+\mathrm{H}_{2} \mathrm{O}+\mathrm{CO}_{2}
$$

\subsection{Methods}

\subsubsection{Mixture}

Table 2 lists the formulation of the aqueous solutions prepared for the corrosion experiments. The corrosion characteristics of sodium chloride, calcium nitrate, and the produced calcium acetate were evaluated.

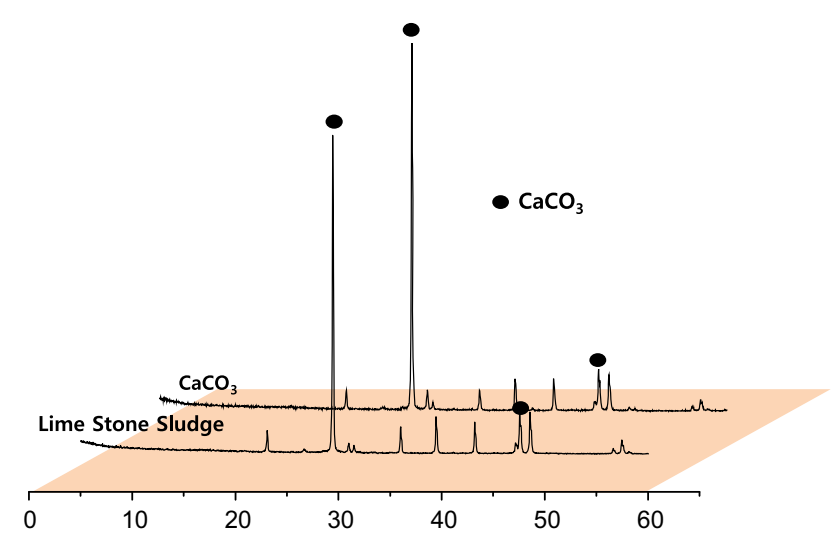

Fig. 2 XRD results of $\mathrm{CaCO}_{3}$ and LSS. 
Table 1 Chemical composition of $\mathrm{CaCO}_{3}$ and LSS (\%).

\begin{tabular}{c|c|c|c|c|c|c|c|c|c}
\hline & $\mathrm{CaO}$ & $\mathrm{SiO}_{2}$ & $\mathrm{MgO}$ & $\mathrm{Al}_{2} \mathrm{O}_{3}$ & $\mathrm{SO}_{3}$ & $\mathrm{Fe}_{2} \mathrm{O}_{3}$ & $\mathrm{P}_{2} \mathrm{O}_{5}$ & $\mathrm{~K}_{2} \mathrm{O}$ & $\mathrm{Na}_{2} \mathrm{O}$ \\
\hline \hline $\mathrm{CaCO}_{3}$ & 96.08 & 0.98 & 2.06 & 0.39 & 0.02 & 0.36 & 0.00 & 0.11 & 0.00 \\
\hline $\begin{array}{c}\text { Lime stone } \\
\text { sludge }\end{array}$ & 90.45 & 3.81 & 1.06 & 2.06 & 0.08 & 1.35 & 0.70 & 0.45 & 0.04 \\
\hline
\end{tabular}

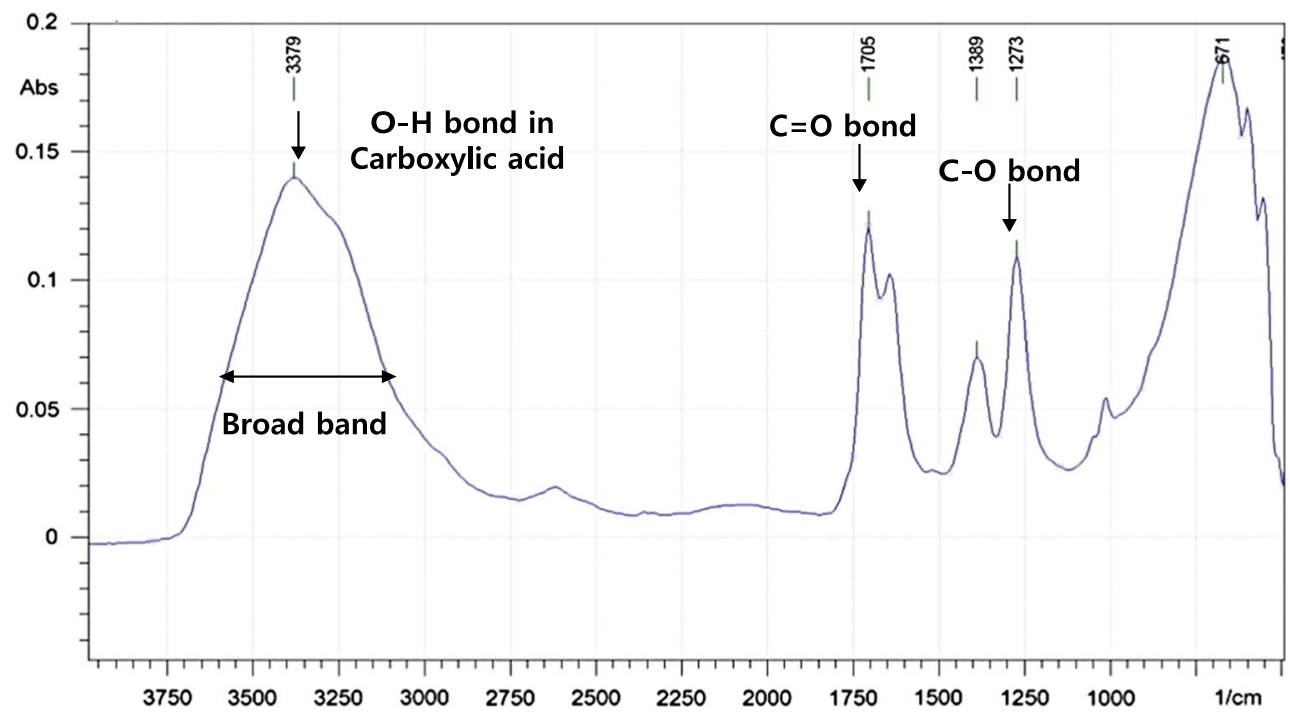

Fig. 3 FT-IR analysis of RAA.

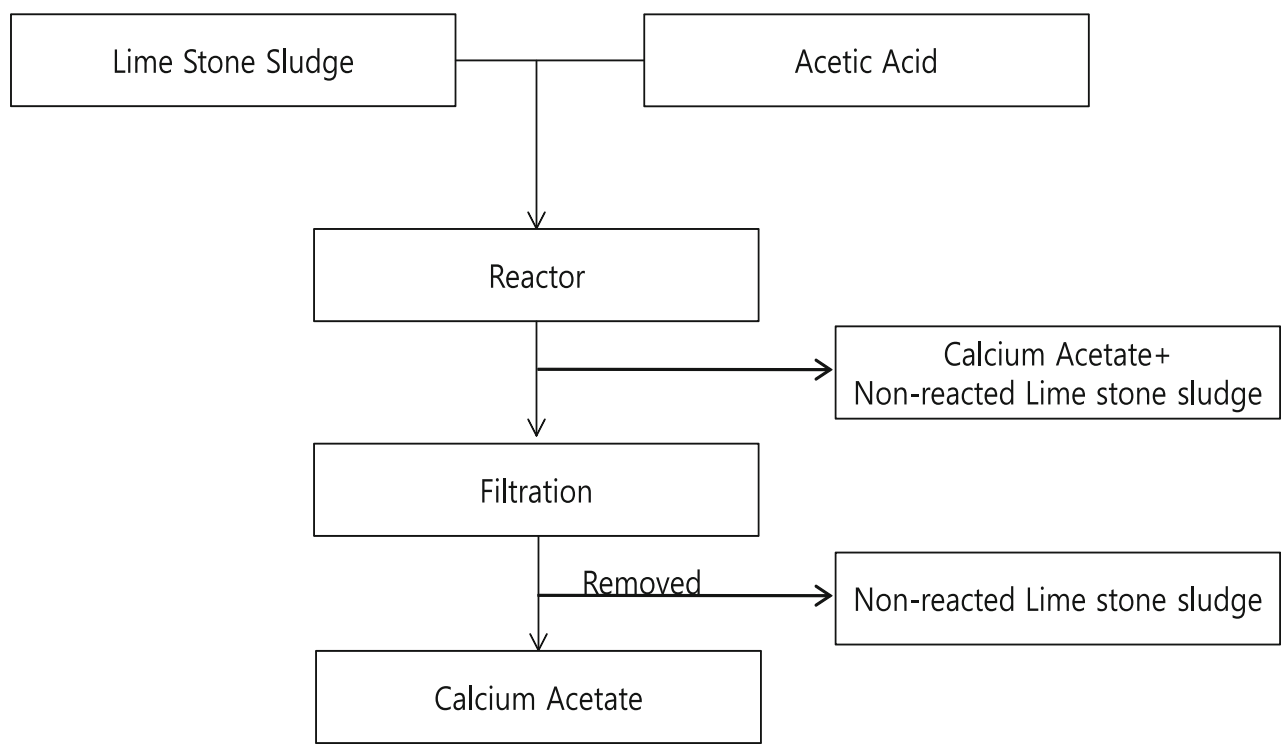

Fig. 4 Process used for manufacturing calcium acetate.

\subsubsection{Corrosion of Steel}

The steel material used for the corrosion experiment was cut into $5 \mathrm{~cm}$ (width) $\times 10 \mathrm{~cm}$ (length) $\times 2 \mathrm{~mm}$ (thickness) plates, which were then immersed in a sodium citrate solution for $3 \mathrm{~h}$ to remove fine rust from their surfaces. Rectangular containers [7 cm (width) $\times 15 \mathrm{~cm}$ (length) $\times 3 \mathrm{~cm}$ (height)] were used to install the steel plates. A $1 \mathrm{~mm}$-thick sponge was placed under each container, and the steel plates were placed in the conductors so that their top and bottom surfaces were in contact with the test solutions. In each of the installed containers, the aqueous solutions (3\%), which were prepared according to the formulations given in Table 2, were poured, and the corrosion state was examined after 1-3 weeks.

\subsubsection{Observation of the Corrosion State}

The corrosion state was examined by calculating the corrosion area rate. The corrosion area was measured by removing the steel plates from the solutions after different intervals of time (1-3 weeks). Oiled grid papers were placed on top of the corroded steel plates to calculate the corrosion area. The weight reduction per unit area resulting from steel 
Table 2 Mixture of deicer (weight \%).

\begin{tabular}{|c|c|c|c|}
\hline & $\mathrm{NaCl}$ & Calcium nitrate & Calcium acetate \\
\hline $\mathrm{NaCl}$ & 100 & - & - \\
\hline Calcium nitrate & - & 100 & - \\
\hline Calcium acetate & - & - & 100 \\
\hline $\mathrm{NaCl} 90 \%+$ Calcium acetate $10 \%$ & 90 & - & 10 \\
\hline $\mathrm{NaCl} 80 \%+$ Calcium acetate $20 \%$ & 70 & - & 30 \\
\hline $\mathrm{NaCl} 50 \%+$ Calcium acetate $50 \%$ & 50 & - & 50 \\
\hline $\begin{array}{c}\text { Calcium nitrate } 90 \%+\text { Calcium } \\
\text { acetate } 10 \%\end{array}$ & - & 90 & 10 \\
\hline $\begin{array}{c}\text { Calcium nitrate } 70 \%+\text { Calcium } \\
\text { acetate } 30 \%\end{array}$ & - & 70 & 30 \\
\hline $\begin{array}{c}\text { Calcium nitrate } 50 \%+\text { Calcium } \\
\text { acetate } 50 \%\end{array}$ & - & 50 & 50 \\
\hline
\end{tabular}

corrosion was obtained by measuring the weights of the steel material before and after the corrosion test and then dividing the weight reduction by the area of the material.

$$
\text { Corrosion area rate }(\text { area } \%)=\frac{\Delta \text { Corrosion area }}{\text { Initial area }} \times 100
$$

$$
\text { Weight Loss by Corrosion }\left(\mathrm{mg} / \mathrm{m}^{2}\right)=\frac{\Delta \text { Weight of Steel }}{\text { Area of Steel }}
$$

\subsubsection{Evaluation of the Electro-Chemical Properties}

Before starting the electrochemical experiments, the steel rebars were exposed to the aqueous solutions of sodium chloride, calcium nitrate, and calcium acetate, and their potentials were stabilized using a potentiostat. These experiments were conducted in a three-electrode system; the specimens worked as the working electrode, a platinum wire acted as the counter electrode, and silver-silver chloride acted as the reference electrode. A working electrode area of $0.78 \mathrm{~cm}^{2}$ was used for all samples.

Electrochemical impedance spectroscopy studies were carried out by changing the frequency of a $10 \mathrm{mV}$ sinusoidal voltage from $100 \mathrm{kHz}$ to $0.1 \mathrm{~Hz}$. DC polarization studies were performed at a scan rate of $1 \mathrm{mV} / \mathrm{s}$ at potentials ranging from -0.3 to $+0.3 \mathrm{~V}$ versus an open circuit potential. The potentiostat used in this study was a VersaSTAT (Princeton Applied Research, Oak Ridge, TN, USA), and the data were analyzed using the Metrohm Autolab NOVA 1.10 software by fitting the experimental data in the constant-phase element model. All electrochemical studies were carried out at $27 \pm 1{ }^{\circ} \mathrm{C}$.

\subsubsection{SEM}

SEM images were used to observe the microstructural changes on the surface of the corroded steel plates.

\section{Results and Discussion}

\subsection{Corrosion Area and Weight Loss}

Table 3 lists the corrosion area and weight loss rates obtained for the sodium chloride, calcium nitrate, and calcium acetate solutions. The corrosion area in the sodium chloride solution was measured by immersing a steel plate into the solution for 1-3 weeks. The corrosion areas were $6.05 \%$ after 1 week, $48.68 \%$ after 2 weeks, and $100 \%$ after 3 weeks. Red and black corrosion were evenly distributed on the surface.

For calcium nitrate, the corrosion area ratio after 1 week was $3.96 \%$ (lower than that in sodium chloride for the same duration). However, after 2 weeks, the corrosion area ratio increased to $95 \%$, which was much higher than that for sodium chloride. The calcium acetate solution showed no corrosion for 2 weeks, and a corrosion area ratio of approximately $1 \%$ was observed after 3 weeks. A thin layer of red corrosion was observed on the surface of the steel plate in this case.

The steel plate that was immersed in a mixture of calcium acetate and sodium chloride showed no corrosion after 1 week. Corrosion began to appear after 2 weeks, depending on the mixing ratio of calcium acetate. After 2 weeks, the corrosion area ratio decreased as the calcium acetate content increased. Corrosion ratios of $6.68,0.83$, and $0.71 \%$ were obtained for 10,30 , and $50 \%$ calcium acetate substitution, respectively. The corrosion area ratio for $10 \%$ calcium acetate substitution after 3 weeks was $36.61 \%$. The corrosion area ratio after 3 weeks at a calcium acetate substitution of $50 \%$ was $1.37 \%$, indicating an improvement in the corrosion potential.

The calcium nitrate/calcium acetate solution began to corrode the steel plate after 2 weeks, which is similar to that observed for the solution containing calcium acetate and sodium chloride. The corrosion area ratios were 10.35, 2.41, and $1.33 \%$ for 10,30 , and $50 \%$ calcium acetate substitution, respectively. Carboxyl groups (like amino groups) tend to be adsorbed onto metal surfaces, thus forming an organic layer. 
Table 3 Corrosion area rate (area \%).

\begin{tabular}{|c|c|c|c|c|c|c|}
\hline & \multicolumn{2}{|c|}{1 Week } & \multicolumn{2}{|c|}{2 Weeks } & \multicolumn{2}{|c|}{3 Weeks } \\
\hline & Measurement & Average & Measurement & Average & Measurement & Average \\
\hline \multirow[t]{3}{*}{$\mathrm{NaCl}$} & 6.05 & \multirow[t]{3}{*}{6.05} & 48.77 & \multirow[t]{3}{*}{48.68} & 100 & \multirow[t]{3}{*}{100.00} \\
\hline & 6.03 & & 49.21 & & 100 & \\
\hline & 6.07 & & 48.05 & & 100 & \\
\hline \multirow[t]{3}{*}{ Calcium nitrate } & 3.96 & \multirow[t]{3}{*}{3.88} & 95.27 & \multirow[t]{3}{*}{95.29} & 98.5 & \multirow[t]{3}{*}{97.37} \\
\hline & 3.92 & & 94.36 & & 96.2 & \\
\hline & 3.76 & & 96.24 & & 97.4 & \\
\hline \multirow[t]{3}{*}{ Calcium acetate } & 0 & \multirow[t]{3}{*}{0} & 0 & \multirow[t]{3}{*}{0.00} & 1.05 & \multirow[t]{3}{*}{1.02} \\
\hline & 0 & & 0 & & 0.89 & \\
\hline & 0 & & 0 & & 1.13 & \\
\hline \multirow{3}{*}{$\begin{array}{c}\mathrm{NaCl} \\
90 \%+\mathrm{Calcium} \\
\text { acetate } 10 \%\end{array}$} & 0 & \multirow[t]{3}{*}{0} & 6.83 & \multirow[t]{3}{*}{6.68} & 36.94 & \multirow[t]{3}{*}{36.61} \\
\hline & 0 & & 6.45 & & 35.74 & \\
\hline & 0 & & 6.76 & & 37.15 & \\
\hline \multirow{3}{*}{$\begin{array}{c}\mathrm{NaCl} \\
70 \%+\mathrm{Calcium} \\
\text { acetate } 30 \%\end{array}$} & 0 & \multirow[t]{3}{*}{0} & 0 & \multirow[t]{3}{*}{0.71} & 6.78 & \multirow[t]{3}{*}{6.79} \\
\hline & 0 & & 1.24 & & 6.84 & \\
\hline & 0 & & 0.89 & & 6.76 & \\
\hline \multirow{3}{*}{$\begin{array}{c}\mathrm{NaCl} \\
50 \%+\mathrm{Calcium} \\
\text { acetate } 50 \%\end{array}$} & 0 & \multirow[t]{3}{*}{0} & 0.9 & \multirow[t]{3}{*}{0.83} & 1.4 & \multirow[t]{3}{*}{1.37} \\
\hline & 0 & & 0.78 & & 1.3 & \\
\hline & 0 & & 0.8 & & 1.41 & \\
\hline \multirow{3}{*}{$\begin{array}{l}\text { Calcium nitrate } \\
90 \%+\text { Calcium } \\
\text { acetate } 10 \%\end{array}$} & 0 & \multirow[t]{3}{*}{0} & 10.3 & \multirow[t]{3}{*}{10.35} & 35.4 & \multirow[t]{3}{*}{35.37} \\
\hline & 0 & & 9.54 & & 36.4 & \\
\hline & 0 & & 11.21 & & 34.3 & \\
\hline Calcium nitrate & 0 & 0 & 2.45 & 2.41 & 21.45 & 20.73 \\
\hline $\begin{array}{c}70 \%+\text { Calcium } \\
\text { acetate } 30 \%\end{array}$ & 0 & & 2.41 & & 20.51 & \\
\hline & 0 & & 2.38 & & 20.23 & \\
\hline Calcium nitrate & 0 & 0 & 1.37 & 1.33 & 6.57 & 6.55 \\
\hline $\begin{array}{c}50 \%+\text { Calcium } \\
\text { acetate } 50 \%\end{array}$ & 0 & & 1.29 & & 6.47 & \\
\hline & 0 & & 1.32 & & 6.62 & \\
\hline
\end{tabular}

Calcium acetate with carboxyl groups can form a complex with ferrous oxide and ferric oxide, and can generate a strong complex on metal surfaces. Terminal carboxyl groups can form a coating on metal surfaces to inhibit corrosion.

The slight red color observed when the calcium acetate solution was used can be attributed to the formation of carboxyl group complexes, which in turn formed a corrosion-inhibiting layer on the surface of the steel plate. Figure 5 shows the oxidation inhibition layer generated by carboxyl groups on the surface of the steel plate (Monticelli et al. 2000). Complexes with carboxyl groups on the surface of the steel interfere with the contact and bonding of oxygen ions and inhibit corrosion in a manner similar to that provided by a film on passive state metals. Figure 6 shows the corrosion characteristics as a function of time.

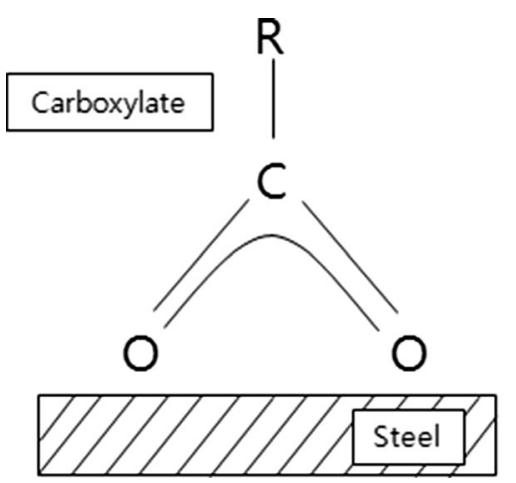

Fig. 5 The oxidation inhibition layer formed by carboxyl groups on the surface of the steel plate (Monticelli et al. 2000). 


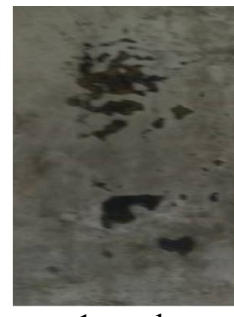

1 week

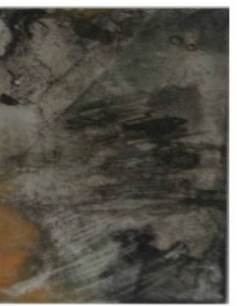

1 week

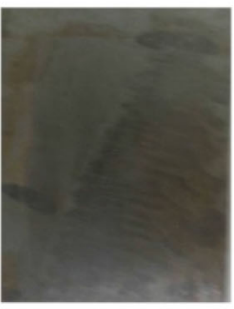

1 week

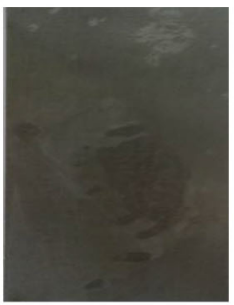

1 week

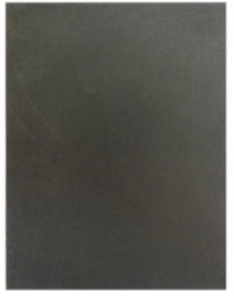

1 week

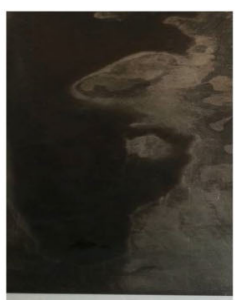

2 weeks

(a)

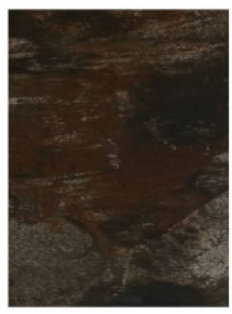

2 weeks

(b)

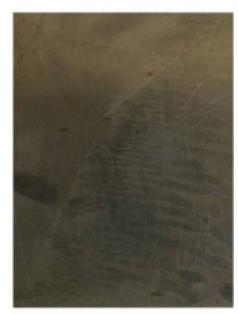

2 weeks

(c)

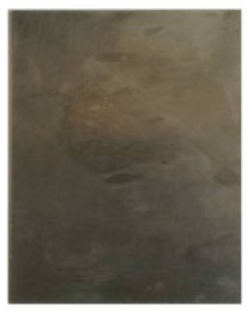

2 weeks

(d)

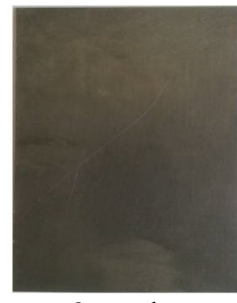

2 weeks

(e)

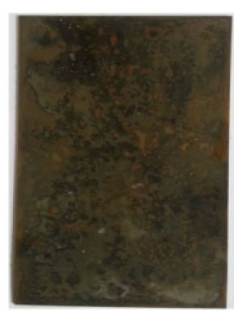

3 weeks

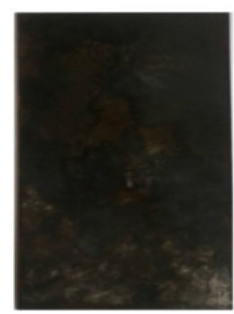

3 weeks

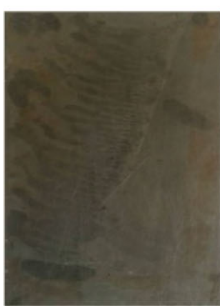

3 weeks

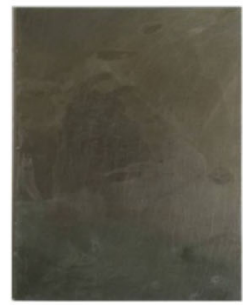

3 weeks

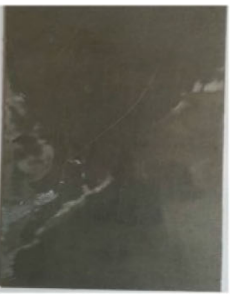

3 weeks
Fig. 6 Corrosion characteristics as a function of time. a Nacl, b $\mathrm{CaN}$, c $\mathrm{CaA}$, d Na-CaA50, e Ca-NA50.
Table 4 presents the weight losses caused by corrosion. The weight reduction, which varies depending on the nature of the aqueous solution, was the greatest using the sodium chloride solution. However, when the specimen was treated with calcium acetate, the weight increased slightly or did not change during the corrosion test.

When calcium acetate was mixed with sodium chloride at a ratio of 1:9, the corrosion-induced weight reduction was $0.81 \mathrm{mg} / \mathrm{cm}^{2}$; at a $50 \%$ mixing rate of calcium acetate, there was almost no weight reduction. When the corrosion area ratios were compared, the corrosion caused by sodium chloride was accompanied by a chipping-off phenomenon after the surface of the steel was corroded; however, when calcium acetate was mixed in the aqueous solution, no chipping-off was observed. Calcium acetate changed the color of the steel surface and prevented corrosion; no steel weight loss was observed. When calcium nitrate was used, the weight reduction caused by corrosion was similar to that provided by the sodium chloride solution, and there was almost no corrosion prevention. Calcium nitrate likely does not provide a surface coating effect, resulting in the loss of steel material by surface corrosion.

\subsection{Electrical Corrosion}

Figures 7, 8 and 9 show the Nyquist plots of calcium acetate, a mixture of calcium acetate and sodium chloride, and calcium nitrate, respectively. A concentric circle was drawn based on the slope of the impedance curve using the impedance method, and the area of this concentric circle was calculated as the corrosion potential value. The maximum electrode resistance of calcium acetate was approximately 7200 , while those of sodium chloride and the mixture of sodium chloride and calcium acetate were 79.8 and 427 , respectively. This indicates that the corrosion potential performance of calcium acetate was higher than that of sodium chloride and that of the sodium chloride/calcium acetate mixture. The resistance value of calcium nitrate was 124 , which is higher than that of $\mathrm{NaCl}$ (79.8). The most favorable corrosion prevention ingredient was calcium acetate because its resistance value was lower than that of the calcium acetate-sodium chloride mixture.

Figure 10 shows the polarization resistance of sodium chloride and calcium acetate. The figure shows that the corrosion current value of the solution with $50 \%$ calcium acetate substitution was higher than that of the sodium chloride solution. The corrosion current of the solution with $50 \%$ calcium acetate substitution was close to zero, indicating a high corrosion potential (Stern and Geary 1957;

Table 4 Weight loss by corrosion $\left(\mathrm{mg} / \mathrm{cm}^{2}\right)$.

\begin{tabular}{c|c|c|c|c|c|c|c|c}
\hline $\mathrm{NaCl}$ & Calcium nitrate & $\begin{array}{c}\text { Calcium } \\
\text { acetate }\end{array}$ & $\begin{array}{c}\mathrm{NaCl} 90 \%+ \\
\text { Calcium } \\
\text { acetate 10\% }\end{array}$ & $\begin{array}{c}\mathrm{NaCl} 70 \%+ \\
\text { Calcium } \\
\text { acetate 30\% }\end{array}$ & $\begin{array}{c}\mathrm{NaCl} 50 \%+ \\
\text { Calcium } \\
\text { acetate 50\% }\end{array}$ & $\begin{array}{c}\text { Calcium nitrate } \\
90 \%+ \\
\text { Calcium } \\
\text { acetate } 10 \%\end{array}$ & $\begin{array}{c}\text { Calcium nitrate } \\
70 \%+ \\
\text { Calcium } \\
\text { acetate } 30 \%\end{array}$ & $\begin{array}{c}\text { Calcium nitrate } \\
50 \%+ \\
\text { Calcium } \\
\text { acetate } 50 \%\end{array}$ \\
\hline \hline 3.54 & 4.21 & -0.03 & 0.81 & 0.24 & 0.04 & 4.27 & 3.89 & 4.12 \\
\hline
\end{tabular}




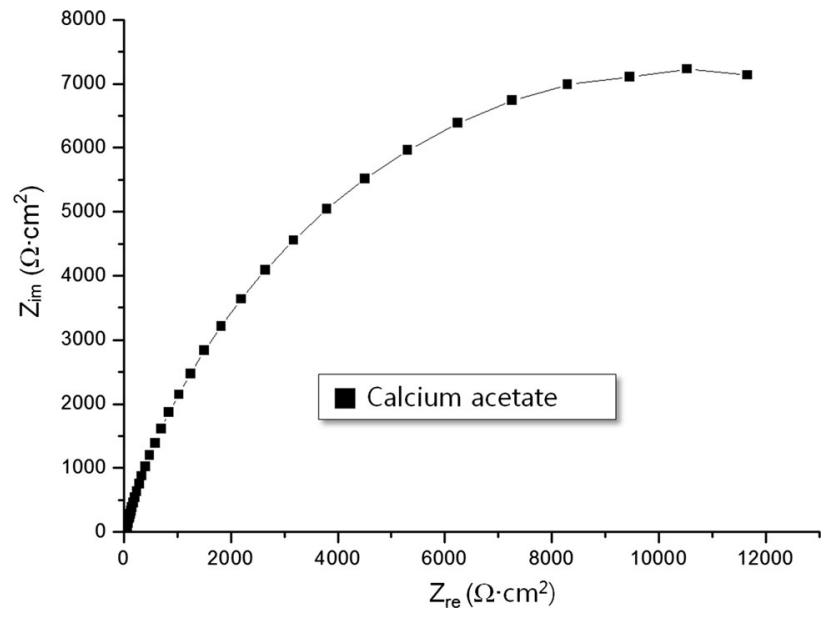

Fig. 7 Nyquist plots of calcium acetate.

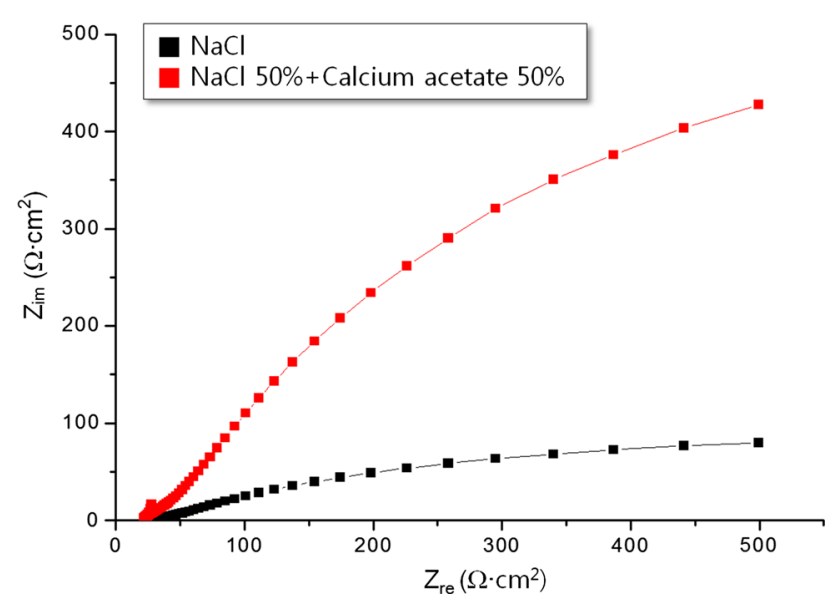

Fig. 8 Nyquist plots of sodium chloride and the mixture of sodium chloride and calcium acetate.

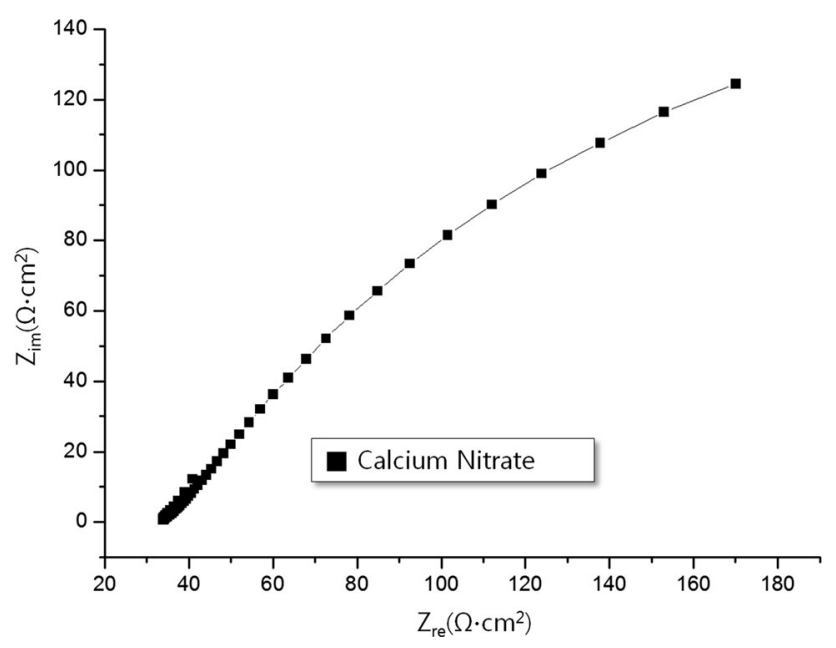

Fig. 9 Nyquist plots of calcium nitrate.

Marcus 1993). When $100 \%$ calcium acetate was used, the corrosion current moved to anodic values and no corrosion was observed. This is because of the reduction reaction caused by the surface adsorption of carboxylic acid.The polarization resistance of calcium nitrate was closer to 0 than that of $\mathrm{NaCl}$, which indicates that its corrosion resistance is superior to that of sodium chloride.

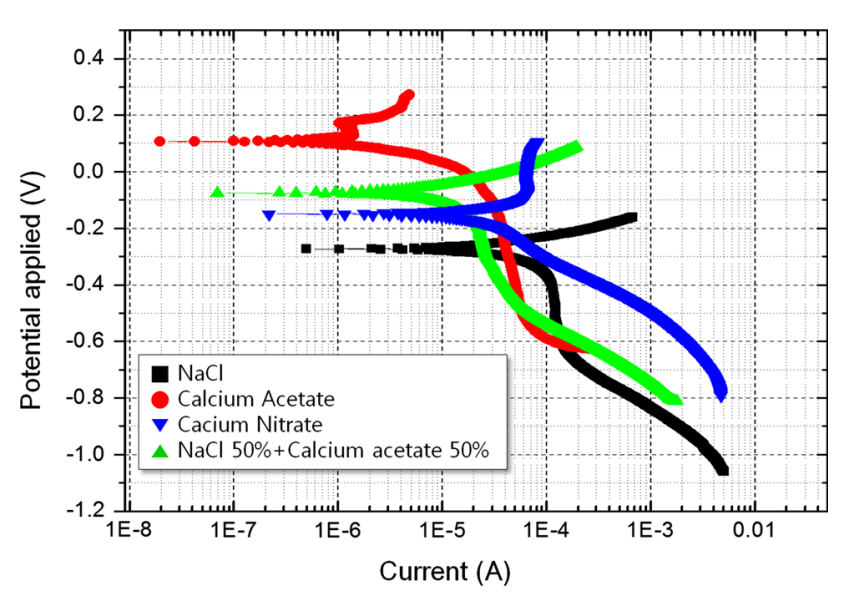

Fig. 10 Polarization resistance of sodium chloride, calcium acetate, calcium nitrate.

\subsection{SEM}

Figure 11 shows SEM images of the cross-section and surface of the steel plates after the corrosion experiment. The steel plate that was immersed in the sodium chloride solution showed a uniform distribution of an amorphous oxide on its surface. Furthermore, the wrinkles, which were present on the surface of the plate before immersion, disappeared and small oxides covered the surface. The surface layer was etched by corrosion. For cross-section corrosion caused by sodium chloride, the corrosion products formed bumps on the surface after corrosion.

When using the mixture of calcium acetate and calcium chloride, oxides were observed at the cross-section of the plate and wrinkles were observed on the surface, indicating that the corrosion of the surface was less intense. In the case of calcium acetate, small octahedral grains were evenly distributed on the surface of the plate, forming an oxide layer. In this case, surface wrinkles were also observed. A corrosion inhibition layer formed because of the complexation of carboxyl groups with the surface of the steel plate.

When using calcium nitrate, the wrinkles on the steel surface disappeared and a coarse-grained coating layer formed on the surface. The nitrate ions (from calcium nitrate) formed an oxide layer of $\mathrm{Fe}_{2} \mathrm{O}_{3}$ on the steel surface to inhibit the progression of corrosion.

Sodium chloride causes surface etching and red corrosion, while calcium nitrate forms coarse particles on the steel surface. The increased corrosion loss was due to the physical properties of the oxide layer, even when the corrosion potential of calcium nitrate was lower than that of sodium chloride. While measuring the corrosion area ratio, the weak oxide layer of calcium nitrate was etched by friction as the surface portion was cleaned, thereby increasing the corrosion area ratio.

The geometry of the cross section was examined after treatment with the sodium chloride-calcium acetate compound; some crystals were observed on the surface, while many crystallization products were evenly distributed for calcium acetate. The crystallization products showed smaller crystal sizes and a more uniform distribution than sodium chloride; therefore, surface reformation is likely caused by the generation of complexes, not surface etching. 


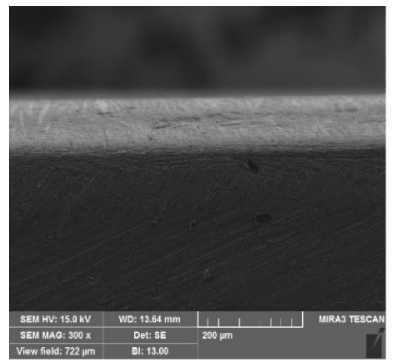

Cross Section

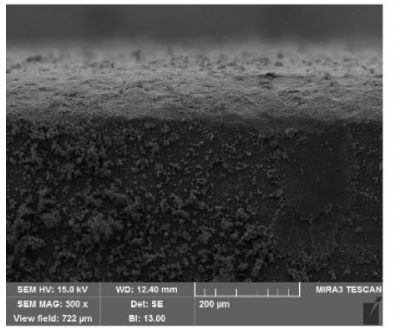

Cross Section

(b)

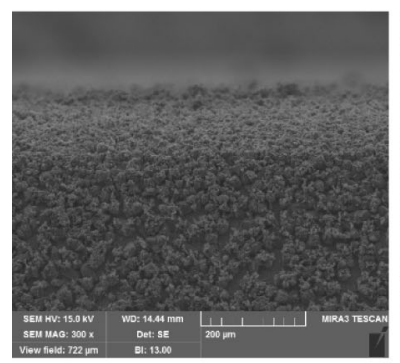

Cross Section

(c)

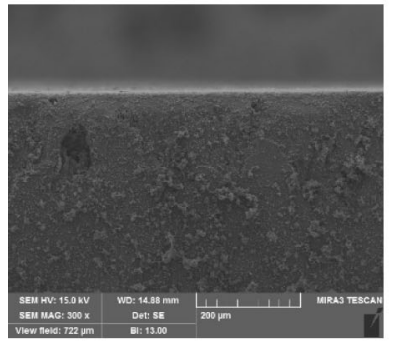

Cross Section

(d)

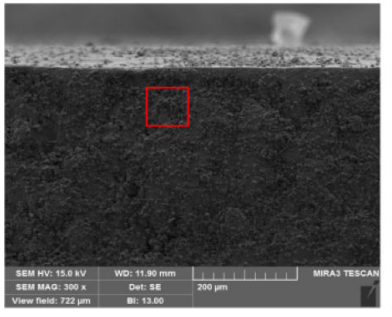

Cross Section

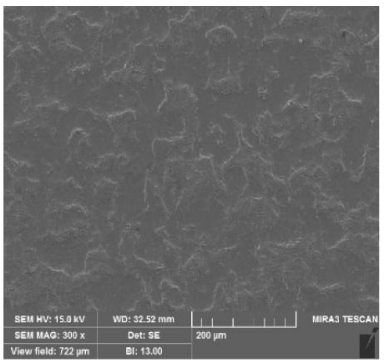

Surface

(a)

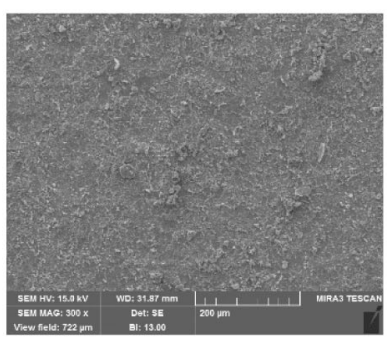

Surface

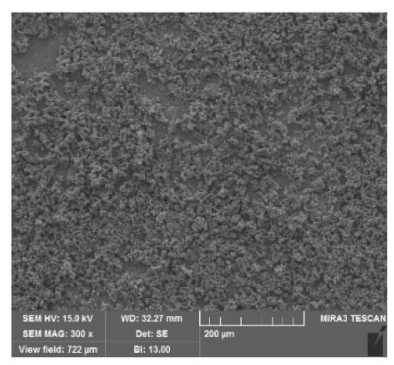

Surface

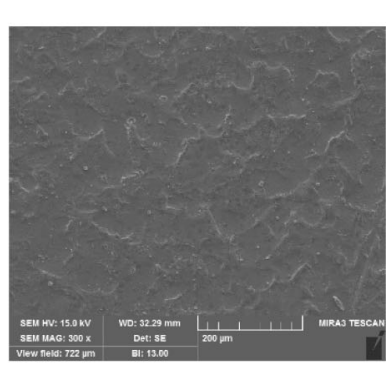

Surface

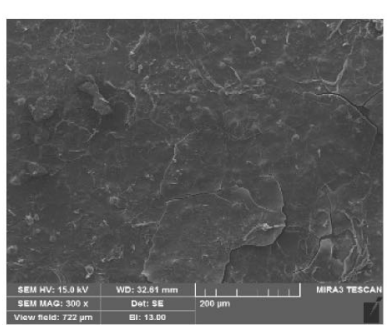

Surface

(e)

Fig. 11 SEM images of the cross-section and surface of the steel plates immersed in various aqueous solutions. a Non-treated, b NaCl, c Calcium Nitrate, d Calcium Acetate $50 \%+\mathrm{NaCl} 50 \%$, e Calcium Acetate 100\%.

\section{Conclusions}

Calcium acetate was produced using industrial by-products. The corrosion characteristics of a steel plate immersed in an aqueous solution of calcium acetate were analyzed by evaluating its corrosion area ratio, weight loss due to corrosion, and electrochemical characteristics. SEM images of the plate were also examined. The results are as follows.

(1) The corrosion experiment using sodium chloride, calcium nitrate, and calcium acetate solutions showed that the corrosion area of the steel plate immersed in calcium nitrate was larger than that of the plate immersed in sodium chloride. No corrosion was observed on the plate immersed in calcium acetate. The corrosion area for the sodium chloride and calcium nitrate solutions decreased with the addition of calcium acetate to these solutions.

(2) Among the three solutions used in this study, the calcium acetate solution showed the largest corrosion potential area, and the corrosion potential value was located on the anode, indicating that it was not susceptible to corrosion. Calcium acetate showed an excellent corrosion potential because it formed an organic coating on the surface with complexes generated by carboxyl groups on metal surfaces.

(3) When a mixture of sodium chloride and calcium acetate was used, the corrosion crystal products on the surface of the metal plate surface were different from those generated in sodium chloride and calcium acetate. The crystal products generated on the surface were similar to those generated in the calcium acetate solution. Here, the surface corrosion caused by sodium chloride was inhibited by the formation of an organic coating on the surface of the steel surface by calcium acetate.

\section{Acknowledgements}

This research was supported by the Research Grant from (Hanyang Experiment \& Consulting) through the Korea Agency for Infrastructure Technology Advancement funded by the Ministry of Land, Infrastructure and Transport of the Korean government (Project No.: 17CTAP-C115066-02).

\section{Open Access}

This article is distributed under the terms of the Creative Commons Attribution 4.0 International License (http:// creativecommons.org/licenses/by/4.0/), which permits un restricted use, distribution, and reproduction in any medium, provided you give appropriate credit to the original author(s) and the source, provide a link to the Creative Commons license, and indicate if changes were made. 


\section{References}

Bazant, Z. P., \& Baweja, S. (1996). Creep and shrinkage prediction model for analysis and design of concrete structures; Model B3. Materials and Structures, 29(2), 126.

Çetin, C., Erdoğan, S. T., \& Tokyay, M. (2016). Effect of particle size and slag content on the early hydration of interground blended cements. Cement \& Concrete Composites, 67, 39-49.

Dodson, V. (1990). Concrete Admixtures, Chapter 4 (pp. 73-102). New York: Van Nostrand Reinhold.

Federal Highway Administration. (2002) corrosion costs and preventative strategies in the United States, Publication No. FHWA-RD-01-156, Federal Highway Administration, Washington D.C.

Han, M. Y. (1991). Shrinkage mechanisms and role of water. Journal of Korea Concrete Institute, 3(2), 46-52.

Hansen, W. (1987). Drying shrinkage mechanisms in portland cement paste. Journal of the American Ceramic Society, 70(5), 323-328.

Heikal, M. (2004). Effect of calcium formate as an accelerator on the physicochemical and mechanical properties of pozzolanic cement pastes. Cement and Concrete Research, 34, $1051-1056$.

Hoang, K., Justnes, H., \& Geiker, M. (2016). Early age strength increase of fly ash blended cement by a ternary hardening accelerating admixture. Cement and Concrete Research, $81,59-69$.

Huang, H., \& Shen, X. D. (2014). Interaction effect of triisopropanolamine and glucose on the hydration of Portland cement. Construction and Building Materials, 65, 360-366.

Kim, D. M., Ryu, H. S., Shin, S. H., \& Park, W. J. (2016). Properties of Calcium Acetate Manufactured with Etching Waste Solution and Limestone Sludge as a Cementitious High-Early-Strength Admixture. Advanced in Materials Science and Engeering. https://doi.org/10.1155/2016/ 2920370.

Le Saoût, G., Lothenbach, B., Hori, A., Higuchi, T., \& Winnefeld, F. (2013). Hydration of Portland cement with additions of calcium sulfoaluminates. Cement and Concrete Research, 43(1), 81-94.

Marcus, R. A. (1993). Electron transfer reactions in chemistryTheory and experiment. Review of Modern Physics, 65 , 599-610.

Messina, F., Ferone, C., Colangelo, F., \& Cioffi, R. (2015). Low temperature alkaline activation of weathered fly ash: influence of mineral admixtures on early age performance. Construction and Building Materials, 86, 169-177.
Min, T. B., Cho, I. S., Park, W. J., Choi, H. K., \& Lee, HanSeung. (2014). Experimental study on the development of compressive strength of early concrete age using calciumbased hardening accelerator and high early strength cement. Construction and Building Materials, 64(14), 208-214.

Monticelli, C., Frignani, A., \& Trabanelli, G. (2000). A study on corrosion inhibitors for concrete application. Cement and Concrete Research, 30, 635-642.

Mussato, B. T. (2003) Guidelines for the selection of snow and ice controlmaterials to mitigate environmental impacts, prepared for the NCHRP Project 6-16.

NS Berke and ARosenberg. (1989). Technical Review of calciumnitrite corrosion inhibitor in concrete. Transportation Research Record, 1211, 18-27.

Ormellese, M., Lazzari, L., Goidanich, S., Fumagalli, G., \& Brenna, A. (2009). A study of organic substances as inhibitors for chloride-induced corrosion in concrete. Corrosion Science, 51, 2959-2968.

Pacific Northwest Snowfighters.(2010) Pacific Northwest snowfighters snow andice control chemical products specifications and test protocols for the PNS Association of British Columbia, Colorado, Idaho, Montana, Oregon and Washington. http:/www.wsdot.wa.gov/partners/pns/pdf/ PNSSPECS.pdf

Seo, S. K., Chu, Y. S., Shim, K. B., Lee, J. K., Song, H., \& Yun, Y. M. (2014). A study on the application limestone sludge to the flue gasdesulfurizationprocess. Journal of the Korean Ceramic Society, 51(6), 575-583.

Shi, X., Fay, L., Gallaway, C., Volkening, K., Peterson, M. M., Pan, T., Creighton, A., Lawlor, C., Mumma, S., Liu, Y.,\& Nguyen, T. A. (2009). Evaluation of alternateanti-icing and deicing compounds using sodium chloride and magnesiumchloride as baseline deicers. Final Report for the Colorado Department of Transportation. Denver, CO. Report No. CDOT-2009-01.

Stern, M., \& Geary, A. L. (1957). Electrochemical polarization: I. A theoretical analysis of the shape ofpolarization curves. Journal of Electrochemical Society, 104, 56-63.

Thamas, M., Natallia, S., Daniel, B., Riding, K. A., \& Zayed, A. (2015). Effect of Chloride and chloride-free accelerators combined with typical admixtures on the early-age cracking risk of concrete repair slabs. Construction and Building Materials, 94(30), 270-279.

World Steel Association. (2015) November 2015 crude steel production. Retrieved November 2015 from https://www. worldsteel.org/media-centre/pressreleases/2015/November2015-crude-steel-production-.html 